\author{
Asian Journal of \\ Medical and Biological Research \\ ISSN 2411-4472 (Print) 2412-5571 (Online) \\ www.ebupress.com/journal/ajmbr
}

\title{
Article \\ Effect of ipil ipil and bean leaves supplementation on egg production, egg quality and growth performance of Japanese quail (Coturnix japonica)
}

\author{
Sumon Sarkar*, Fahima Binthe Aziz, Md. Mahmudul Hasan, Rakibul Islam and Misrat Masuma Parvez \\ Department of Physiology and Pharmacology, Hajee Mohammad Danesh Science and Technology University, \\ Dinajpur, Bangladesh
}

*Corresponding author: Sumon Sarkar, Dept. of Physiology and Pharmacology, Hajee Mohammad Danesh Science and Technology University, Dinajpur, Bangladesh. Phone: +8801721545509; E-mail: sarkarsumon.setu@gmail.com

Received: 07 June 2018/Accepted: 25 June 2018/ Published: 30 June 2018

\begin{abstract}
This study was conducted to determine the effect of ipil ipil and bean leaves supplementation on egg production, egg quality and growth performance of Japanese quail. A total of 40 "Japanese Quail" at the age of 42 days ( 06 weeks) old were divided into four groups $\mathrm{T}_{0}, \mathrm{~T}_{1}, \mathrm{~T}_{2}$ and $\mathrm{T}_{3}$ respectively. Group $\mathrm{T}_{0}$ was considered as control which fed only with commercial layer ration. Group $\mathrm{T}_{1}$ was supplemented with formulation of $2 \mathrm{gm}$ grinded ipil ipil leaves, Group $\mathrm{T}_{2}$ with $2 \mathrm{gm}$ grinded Bean leaves and Group $\mathrm{T}_{3}$ with $2 \mathrm{gm}$ grinded ipil ipil leaves plus $2 \mathrm{gm}$ grinded Bean leaves per $\mathrm{kg}$ feed respectively. Observations were recorded for growth performance, egg production and egg quality of quail. Increased egg production rate was observed in ipil ipil supplemented groups (group $\mathrm{T}_{1}$ ). Body weights were increased significantly $(\mathrm{p}<0.05)$ in all treated groups in respect to the control and highest was recorded in combined ipil ipil and Bean leaves supplemented groups (Group $\mathrm{T}_{3}$ ). In treatment groups, there were significant increase in egg production, but in case of control group, the egg production was not increased. There was no significant pathological change in any internal organs of the layer of treated groups. Best result was found in the group $\mathrm{T}_{3}$. The present study reveals that combined supplementation of ipil ipil and bean leaves gives better result over the other groups in respect to growth performance, egg production and egg quality.
\end{abstract}

Keywords: ipil ipil; bean leaves; egg and growth performances; Japanese quail

\section{Introduction}

Bangladesh is a highly populated country and growth of population is increasing very fast in comparison to its land size, as a result huge pressure is created on people's basic needs. Demand of protein of this booming population is a great threat for us. There are so many sources of protein but it is impossible to fulfill the demand without Poultry meat and egg. Different types of poultry are present; quail is one of them. Quail meat is popular to all of us and there is no religious restriction to consume. According to our socio-economic situation, the knowledge of our farmer is very little because most of them are not properly trained for quail production.

Now a day's our unemployed young generation is coming in this business for long return of value and profit. Pharmaceutical companies take this advantage. They are convincing farmers for using synthetic phytase as a growth promoter and egg increaser for chicken as well as quail (Yu et al., 2004). As a result, each and every quail is a depot of antibiotics and other inorganic substances. When these quails are consumed by human these antibiotic and other inorganic residue enters into human body and causing serious human health hazards with drug resistance (Sarker et al., 2018). So, scientists are again concentrating on the use of our ancient medicinal system to find beneficial herbs and plants which can be safely used to increase the production (Talukder $e t$ al., 2017). Such plants, ipil ipil (Leucaena leucocephala) and bean (Dolichos lablab) are common plant which can be used as an alternative source of phytase. 
A phytase (myo-inositol hexakisphosphate phosphohydrolase) is any type of phos-phatase enzyme that catalyzes the hydrolysis of phytic acid (myo-inositol hexakis-phosphate) - an indigestible, organic form of phosphorus that is found in grains and oil seeds - and releases a usable form of inorganic phosphorus (Anna et al., 2014). While phytases have been found to occur in animals, plants, fungi and bacteria, phytases have been most commonly detected and characterized from fungi (Tang et al., 2012). Phytic acid and its metabolites have several important roles in seeds and grains, most notably, phytic acid functions as a phosphorus store, as an energy store, as a source of cations and as a source of myo-inositol (a cell wall precursor). Phytic acid is the principal storage forms of phosphorus in plant seeds and the major source of phosphorus in the grain-based diets used in intensive livestock operations (Ahmed et al., 2012). The organic phosphate found in phytic acid is largely unavailable to the animals that consume it, but the inorganic phosphate that phytases release can be easily absorbed. Ruminant animals can use phytic acid as a source of phosphorus because the bacteria that inhabit their gut are well characterized producers of many types of phytases (Attia et al., 2012). However, monogastric animals do not carry bacteria that produce phytase, thus, these animals cannot use phytic acid as a major source of phosphorus and it is excreted in the feces (Casartelli et al., 2004). Phytase is used as an animal feed supplement often in poultry and swine - to enhance the nutritive value of plant material by liberation of inorganic phosphate from phytic acid (myo-inositol hexakisphosphate).

Phytate is the major form of phosphorus found in cereal grains, beans and oilseed meals feed to poultry birds (Ravindran et al., 1994). Approximately 61-70\% phosphorus found in poultry diet ingredients is in the form of phytatephosphorus. But the monogastric animals like poultry birds are unable to utilize this phytate phosphorus, as they lack endogenous phytase, which necessitates in the addition of inorganic feed containing phosphates to poultry diets in order to meet the phosphorus requirements of poultry (Tischler et al., 2015). It results in relatively large amounts of phosphorus in the manure that contribute to environmental pollution (Guoy et al., 2009). Exogenous phytase of microbial origin can be used as an alternative that can help to reduce phosphorus excretion in poultry (Kibria et al., 2009). The beneficial effect of exogenous phytase in poultry ration has been supposed to be due to the direct hydrolytic effects on phytate and the subsequent improvement in the availability of minerals, amino acids, and energy (Selle and Ravindran, 2007). It has also been suggested that phytase in poultry diets improves gut health as indicated by reduced secretions from the gastrointestinal tract (GIT) which consequently improves the efficiency of utilization of energy (Oduguwa et al., 2007; Pirgozliev et al., 2008). The main objective of this current review therefore is to determine the effect of dietary phytase feed additives on the growth performance, feed efficiency, protein/ amino acid digestibility, energy utilization, mineral retention, and bone growth and egg production of quail. By realizing all sorts of problem we are planning to rear quail by using herbal medication like ipil ipil and bean leaves extract instead of any synthetic agent, to avoid human health hazards as well as economic Quail production in Bangladesh.

\section{Materials and Methods}

\subsection{Experimental design}

The experiment was conducted at the Department of Physiology and Pharmacology, Hajee Mohammad Danesh Science and Technology University, Dinajpur. A total of 40 quails are randomly selected and divided into 4 groups $\left(T_{0}, T_{1}, T_{2}\right.$ and $\left.T_{3}\right)$ for assessing the effect of ipil ipil and bean leaves supplementation on egg production, egg quality and growth performance of quail. Group $\mathrm{T}_{0}$; considered as control, fed only with commercial layer ration, group $\mathrm{T}_{1}$; supplemented with formulation of $2 \mathrm{~g}$ grinded ipil ipil leaves per $\mathrm{kg}$ feed, group $\mathrm{T}_{2}$; supplemented with formulation of $2 \mathrm{~g}$ grinded bean leaves per $\mathrm{kg}$ feed and group $\mathrm{T}_{3}$; supplemented with formulation of $2 \mathrm{~g}$ grinded ipil ipil leaves with $2 \mathrm{~g}$ grinded bean leaves per $\mathrm{kg}$ feed. All the quail of control and treated groups were closely observed for 4 weeks and following parameters were studied.

\subsection{Collection and management of quails}

At 42 days of age, Japanese layer quails were collected from A. R. Enterprise (quail hatchery and farm), Bogra. Body weights of assigned quails were taken with digital weight balance and the data were recorded. The finally selected 40 quails were housed under normal husbandry condition and reared quail in quail cage. All the birds were fed with commercial crumbled and mesh feed at the rate of $30 \mathrm{~g}$ per bird per day and fresh water adlibitum. Measurement of body weight was performed with the help of digital balance.

\subsection{Collection and preparation of experimental diet}

Ipil ipil and bean leaves were collected from the Brac Nursery, Dinajpur. The ipil ipil and bean leaves were dried and grinded. The grinded leaves were added with commercial quail ration and served to recommended groups. 


\subsection{Egg production record}

Egg production was recorded for each quail at the same time each day during laying period. The incidence of broken eggs and soft-shelled eggs were identified and recorded. The number of eggs laid on successive days by a particular quail determined the length of each sequence and the number of pauses in each quail's oviposition determined the number of sequences. For each quail, the length of laying sequence was determined on the day the last egg of the quail was laid.

\subsection{Observation of egg quality}

Egg qualities wear measured from those eggs laid by quails of different treatment group. Measured egg qualities were egg weight, shell dry weight, fresh albumin weight, fresh yolk weight, egg shell thickness, height of the thick albumin, height of the yolk, width of the yolk, width of the egg, and diameter of the egg albumin. For quality determination egg weight was recorded by an electric weighing balance. The length of egg was measured by a slide calipers. The width was also estimated by slide calipers. The eggs were then carefully broken down on a glass plate $(40 \times 20 \mathrm{~cm})$ to determine the internal egg qualities.

\subsection{Weight of different egg component}

The method outlined by Chowdhury (1988) was followed for partition in different egg components. At first, egg was broken on glass plate. Then the yolk was separated carefully from albumin with the help of a spatula and transferred to a previously weighed petridish by a spatula and weighed. Precautions wear taken at all stages to avoid rupture of yolk. The shell of the broken eggs wear rinsed and washed thoroughly in tap water keeping the membranes intake. The washed shells with membrane were immersed in a beaker of water for removal of the shell membranes. The shell and shell membranes were oven dried separately at $105^{\circ} \mathrm{C}$ over night keeping them in a glass petridish. On the following day, oven dried shell and shell membranes were taken. Finally the following calculations were made for different components suggested by Chowdhury (1988).

Fresh yolk weight: (weight of yolk + weight of petridish) - weight of petridish.

Fresh albumin weight: (Weight of wet albumin + weight of petridish) - weight of petridish.

\subsection{Shell thickness}

After removing of shell membrane, shell thickness (mm) was measured by screw gauge.

\subsection{Statistical analyses}

Data were analyzed by analysis of variance using Completely Randomized Design with factorial arrangement of time and treatments (Steel and Torrie, 1986). All analyses wear performed by MSTATC and SPSS program.

\section{Results and Discussion}

This study investigated the effect of ipil ipil and bean leaves supplementation on growth performance, egg production and egg quality of quail.

\subsection{Egg Production}

Egg production of different groups of quail were recorded from 6 weeks to 10 weeks quail treated with ipil ipil, bean leaves and combined ipil ipil plus bean leaves. The average egg production of different groups of quail were recorded. Quails treated with ipil ipil leaves showed average egg production 21.8 \pm 0.32 within 06-10 weeks, bean leaves treated groups showed average egg production $22.5 \pm 0.50$ and combined treatment supplementation showed average egg production $23.3 \pm 0.47$ within 6 weeks to 10 weeks (Table 1). Control group showed average egg production $17.5 \pm 0.34$. Result showed highest egg production in combined treatment group (23.3 \pm 0.47$)$ and lowest in control group (17.5 \pm 0.34$)$. Moreover, ipil ipil and bean leaves supplementation increase egg production. Similar results were observed by Mills et al., (1997); Panda et al., (2008) and Gao et al., (2013). 
Table 1. Egg production of quail.

\begin{tabular}{lll}
\hline Treatment Groups & Egg production(06-10weeks) & Percentage (\%) \\
\hline $\mathrm{T}_{0}$ (control) & $17.50^{\mathrm{c}} \pm 0.34$ & $45.71 \%$ \\
$\mathrm{~T}_{1}$ (ipil ipil) & $21.80^{\mathrm{b}} \pm 0.33$ & $55.47 \%$ \\
$\mathrm{~T}_{2}$ (bean leaves) & $22.50^{\mathrm{ab}} \pm 0.50$ & $57.38 \%$ \\
$\mathrm{~T}_{3}$ (ipil ipil+bean ) & $23.30^{\mathrm{a}} \pm 0.47$ & $59.28 \%$ \\
\hline
\end{tabular}

Note: Values followed by different superscripts in the same column are statistically significant $(\mathrm{p}<0.05)$.

\subsection{Body growth}

Body weight of different groups of quails were recorded from 06 to 10 weeks quail treated with ipil ipil leaves, bean leaves and combined ipil ipil plus bean leaves. The average body weight of different group of quails was recorded. Quails treated with ipil ipil leaves showed average Body weight gain 123.5 \pm 3.30 to $149.2 \pm 5.14 \mathrm{gm}$ within 06-10 weeks, bean leaves treated groups showed body weight gain $123.8 \pm 3.42$ to $149.0 \pm 6.49$ gm and combined treatment supplementation showed body weight $126.8 \pm 2.78$ to $155.1 \pm 7.15$ gm within $06-10$ weeks (Table 2). Control group showed average body weight gain $128.5 \pm 4.00$ to $151.9 \pm 5.48 \mathrm{gm}$. Result showed that the body weights of different groups more or less same with the control group. Similar findings was observed by Saima et al. (2014).

Table 2. Body weight gain of quail.

\begin{tabular}{lll}
\hline \multirow{2}{*}{ Group } & \multicolumn{2}{c}{ Body weight (gm.) } \\
\cline { 2 - 3 } & 06 weeks (starting of the experiment) & End of 10 weeks \\
\hline $\mathrm{T}_{0}$ & $128.5^{\mathrm{a}} \pm 4.00$ & $151.9^{\mathrm{a}} \pm 5.48$ \\
$\mathrm{~T}_{1}$ & $123.5^{\mathrm{a}} \pm 3.30$ & $149.2^{\mathrm{a}} \pm 5.14$ \\
$\mathrm{~T}_{2}$ & $123.8^{\mathrm{a}} \pm 3.42$ & $149.0^{\mathrm{a}} \pm 6.49$ \\
$\mathrm{~T}_{3}$ & $126.8^{\mathrm{a}} \pm 2.78$ & $155.1^{\mathrm{a}} \pm 7.15$ \\
\hline
\end{tabular}

N.B: Values followed by same superscripts in the same column are not statistically significant $(\mathrm{p}<0.05)$.

\subsection{Egg quality}

Table 3 demonstrate that there exist a significant $(\mathrm{P}<0.05)$ difference among the mean values like Length of the egg $(\mathrm{mm})$, height of the thick albumin $(\mathrm{mm})$, diameter of the albumin $(\mathrm{mm})$, shell thickness $(\mathrm{mm})$ corresponding to the different level of ipil ipil and bean leaves treatment. But no significant $(\mathrm{P}>0.05)$ difference among the mean values like weight of the egg $(\mathrm{gm})$, width of the egg $(\mathrm{mm})$, height of the yolk $(\mathrm{mm})$, width of the yolk $(\mathrm{mm})$, shell dry wt (gm) corresponding to the different level of ipil ipil and bean leaves treatment. These results indicate that treated with ipil ipil and bean leaves had no adverse effect on external and internal qualities of eggs.

Table 3. Effect of ipil ipil, bean leaves and combined treatment on egg quality parameters of quail

\begin{tabular}{lllll}
\hline Parameter & $\begin{array}{l}\text { Group T } \\
(\text { Mean } \pm \text { SEM) }\end{array}$ & $\begin{array}{l}\text { Group T } \\
(\text { Mean } \pm \text { SEM) }\end{array}$ & $\begin{array}{l}\text { Group T }_{\mathbf{2}} \\
(\text { Mean } \pm \text { SEM) }\end{array}$ & $\begin{array}{l}\text { Group T } \\
(\text { Mean } \pm \text { SEM) }\end{array}$ \\
\hline Weight of the Egg (g) & $09.70^{\mathrm{b}} \pm 0.633$ & $10.20^{\mathrm{b}} \pm 0.512$ & $09.80^{\mathrm{b}} \pm 0.663$ & $10.50^{\mathrm{a}} \pm 0.341$ \\
Width of the Egg (mm) & $25.67^{\mathrm{a}} \pm 0.065$ & $25.54^{\mathrm{a}} \pm 0.060$ & $25.14^{\mathrm{b}} \pm 0.063$ & $24.74^{\mathrm{c}} \pm 0.182$ \\
Height of Thick Albumin (mm) & $3.14^{\mathrm{b}} \pm 0.073$ & $3.39^{\mathrm{a}} \pm 0.048$ & $3.60^{\mathrm{a}} \pm 0.097$ & $3.54^{\mathrm{a}} \pm 0.061$ \\
Length of Egg (mm) & $32.66^{\mathrm{a}} \pm 0.148$ & $31.21^{\mathrm{b}} \pm 0.301$ & $30.98^{\mathrm{b}} \pm 0.230$ & $32.06^{\mathrm{a}} \pm 0.249$ \\
Diameter of Albumin (mm) & $45.59^{\mathrm{a}} \pm 0.116$ & $42.79^{\mathrm{c}} \pm 0.257$ & $43.76^{\mathrm{b}} \pm 0.293$ & $41.34^{\mathrm{d}} \pm 0.242$ \\
Height of Yolk (mm) & $6.61^{\mathrm{b}} \pm 0.111$ & $6.84^{\mathrm{ab}} \pm 0.107$ & $6.12^{\mathrm{c}} \pm 0.086$. & $6.92^{\mathrm{a}} \pm 0.103$ \\
Egg shell thickness (mm) & $0.17^{\mathrm{b}} \pm 0.008$ & $0.16^{\mathrm{c}} \pm 0.009$ & $0.12^{\mathrm{d}} \pm 0.004$ & $0.19^{\mathrm{a}} \pm 0.007$ \\
Width of the yolk (mm) & $29.52^{\mathrm{b}} \pm 0.127$ & $29.63^{\mathrm{b}} \pm 0.109$ & $28.15^{\mathrm{c}} \pm 0.384$ & $30.60^{\mathrm{a}} \pm 0.285$ \\
Shell dry weight (g) & $3.19^{\mathrm{a}} \pm 0.058$ & $3.05^{\mathrm{b}} \pm 0.050$ & $3.13^{\mathrm{ab}} \pm 0.105$ & $3.38^{\mathrm{a}} \pm 0.089$ \\
\hline
\end{tabular}

Note: Values followed by same superscripts in the same column are not statistically significant $(p>0.05)$, different superscripts indicate that difference is significant $(\mathrm{P}<0.05)$.

$*=$ Significance at the $0.05 \%$ level

NS = Non significance 


\section{Conclusions}

In our research project egg production and body weights were increased in ipil ipil and bean leaves supplementation. From the present field and laboratory trial, it can be concluded that combined supplementation of grained ipil ipil and bean leaves is highly beneficial for enhancing egg production without making any hazards of Japanese quail and our formulations could be used as an egg enhancer and growth promoter for layer especially for older quail.

\section{Conflict of interest}

None to declare.

\section{References}

Ahmed ES, EK Nasser, MZ Kamelia, EA Tahia and AE Fathy, 2012. Effect of Dietary Enzyme supplementation on Egg Laying Performance and Nutrient Digestibility of Japanese Quails. IJAVMS, 6: 377-384.

Anna M, L Martina and P Alena, 2014. Effect of exogenous phytase on egg quality in laying hens. Acta fytotechn. zootechn., 17: 79-83.

Attia YA, WS El-Tahawy, E Abd El-Hamid, SS Abd El-Hamid, AN Hassan and MI El-Kelaway, 2012. Effect of phytase with or without multienzyme supplementation on performance and nutrient digestibility of young broiler chicks fed mash or crumble diets. Italian Journal of Animal Science, 11: 303-308.

Casartelli EM, OM Junqueira, AC Laurentiz, RS Filardi, JJ Lucas and LF Araujo, 2004. Effect of phytase in laying hen diets with different phosphorus sources. Rev. Bras. Cienc. Avic., 7: 93-98.

Chowdhury EH, N Shimada, H Murata, O Mikami, P Sultana, S Miyazaki, M Yoshioka, N Yamanaka, N Hirai and Y Nakajima, 1988. Detection of Cry1Ab protein in the gastrointestinal contents but not in the visceral organs of genetically modified Bt11-fed calves. Vet. Hum. Toxicol., 45: 72-75.

Gao CQ, C Ji, JY Zhang, LH Zhao and QG Ma, 2013. Effect of a novel plant phytase on performance, egg quality, apparent ileal nutrient digestibility and bone mineralization of laying hens fed corn-soybean diets. Anim. Feed Sci. Technol., 186: 101-105.

Guoy, Y Shi, F Li, J Chen, C Zhen and Z Hao, 2009. Effects of sodium gluconate and phytase on performance and bone characteristics in broiler chickers. Anim. Feed Sci. Technol., 150: 270-282.

Kibria K, F Nur, SN Begum, MM Islam, SK Paul, KS Rahman SMM Azam, 2009. Molecular marker based genetic diversity analysis in aromatic rice genotypes using SSR and RAPD markers. Int. J. Sustain. Crop Prod., 4: 23-34.

Mills AD, LL Crawford, M Domjan and JM Faure, 1997. The Behavior of the Japanese or Domestic Quail Coturnix japanica. Neuroscience and Biobehavioral Reviews, 21: 261-281.

Oduguwa O, V Pirgozliev and T Acamovic, 2007. Energy metabolizability and digestibility of amino acids by broilers fed malted sorghum sprouts supplemented with polyethylene glycol, charcoal, phytase and xylanase. Br. Poult. Sci., 48: 55-63.

Panda AK, VRB Sastry and AB Mandal, 2008. Growth, nutrient utilization and carcass characteristics in broiler chickens fed raw and alkali processed solvent extracted karanj (Pongamia glabra) cake as partial protein supplement. J. Poult. Sci., 45: 199-205.

Pirgozliev V, O Oduguwa, T Acamovic and MR Bedford, 2008. Effects of dietary phytase on performance and nutrient metabolism in chickens. Br. Poult. Sci., 49: 144-154.

Ravindran V, G Ravindran and S Sivalogan, 1994. Total and phytate phosphorus contents of various foods and feedstuffs of plant origin. Food Chem., 50:133-136.

Saima, MA Shad, TN Pasha, M Akram, YA Ditta and MZU Khan, 2014. Effect of microbial phytase supplementation on growth performance of Japanese quails. J. Anim. Plant Sci., 24: 19-23.

Sarker YA, MM Hasan, TK Paul, SZ Rashid, MN Alam and MH Sikder, 2018. Screening of antibiotic residues in chicken meat in Bangladesh by thin layer chromatography. J. Adv. Vet. Anim. Res., 5:140-145.

Selle PH and V Ravindran, 2007. Microbial phytase in poultry nutrition. Anim. Feed Sci. and Technol., 135: 141.

Steel RGD and JH Torrie, 1986. Principles and procedures of statistics: a biometrical approach. 2nd ed. New York: McGraw-Hill, p. 633.

Talukder S, MM Hasan, ZA Noman, YA Sarker, TK Paul and MH Sikder, 2017. Effect of dietary supplementation of ginger extract on growth, carcass characteristics and haematological parameters in broilers. Asian J. Med. Biol. Res., 3: 211-215. 
Tang HO, XH Gao, F Ji, S Tong and XJ Li, 2012. Effects of a thermostable phytase on the growth performance and bone mineralization of broilers. J. Appl. Poult. Res., 21: 476-483.

Tischler A, V Halas and J Tossenberger, 2015. Effect of dietary NPP level and phytase supplementation on the laying performance over one year period. Poljo Privreda, 21: 68-72.

Yu B, YC Jana, TK Chungb, TT Leea, PWS Chioua, 2004. Exogenous phytase activity in the gastrointestinal tract of broiler chickens. Anim. Feed Sc. Tech., 117: 295-303. 